\title{
Book Review: Community Radio Policies in South Asia by Preeti Raghunath
}

\author{
Padmaja Shaw \\ Osmania University, Hyderabad, India, padmajashaw@gmail.com
}

\begin{abstract}
Padmaja Shaw reviews "Community Radio Policies in South Asia" by Preeti Raghunath. Raghunath applies "deliberative policy ecology approach" to study how policy frameworks evolved in four South Asian nations, India, Bangladesh, Nepal and Sri Lanka. Raghunath argues that the "deliberative policy ecology approach" is rooted in emancipatory politics that brings in the stakeholders at the bottom of the policy food chain. Raghunath's intricate map of policy formulation in post-colonial societies is an engaging revelation of the continued contradictions between the developmentalist instincts of the state and the push of grassroots voices to claim their legitimate space in decision making.
\end{abstract}

Keywords: Community radio, South Asia, deliberative policy ecology, political economy, media policy

Paulo Freire wrote the book Pedagogy of the Oppressed in 1968, when the youth of the Western world was confronting unjust wars and were dreaming of a better world. The Freirean vocabulary in the Pedagogy was tangibly meaningful as it spread across post-colonial Latin America, Africa and Asia. The 1970s and 1980s were the years when "conscientisation", education as "dialogical" as opposed to "banking", and "praxis" that meant knowledge-driven social action, were widely discussed and led to many attempts at building grassroots institutions.

Though the use of independent radio began in the 1940s in Latin America, its deployment as a tool for conscientisation intensified after the 1960s. Bolivia, Columba, Peru, Brazil and others saw the emergence of dozens of radio stations, some under the wing of the Catholic church that espoused "Liberation Theology", to spread education that deepened political consciousness among the poor and the marginalised. "Participatory communication" appeared as an alternative strategy to mainstream commercial communication in many countries.

It was in the early 1980s that the movement for community radio stations began to appear in South Asian countries like Sri Lanka and Nepal, according to a comprehensive account of the process, "Community Radio Policies in South Asia", the book written by a young scholar Preeti Raghunath and published by Palgrave Macmillan.

Raghunath attempts a gamut of innovations in her project to map the birth and evolution of the Community Radio movement in the South Asian region from a public policy perspective. Methodologically, she espouses "deliberative policy ecology approach" that allows her to transcend the limitations natural to conventional methods in policy research such as document analysis or case studies.

In the first chapter, the book Community Radio Policies in South Asia lays out the range of perspectives and theoretical approaches that already have shaped policy studies, and media policy studies in particular. Through a thorough scrutiny of extant theoretical possibilities, the author acknowledges the criticality of political economy and 
history, and the need for a grounded approach to looking at media policy whose communicative space itself tends to be the platform for other discourses.

The fortunes of Community Radio, itself of grassroots, tend to get determined by policy actors from the activist, the political or the bureaucratic spaces. Raghunath argues that deliberative policy ecology approach brings into policy reckoning the perspectives of those who run the radio stations and those who consume the content as well.

Raghunath begins by grappling with the definitional issues, the myth of policy-making as a neutral, apolitical enterprise, and the techno-centric approach that had greater traction in media policy study thus far. She examines the policy-making processes from four South Asian countries - India, Nepal, Bangladesh, and Sri Lanka - drawing from a wide array of ideas ranging from political economy perspective, grounded theory, to history.

Raghunath outlines the historical context in which the community radio projects were conceived in each of the countries, giving us an insight into the way policy gets moulded by the constraints of political circumstances. Nepal,and Sri Lanka were coping with insurgencies that made it possible for the emergence of independent radio. Bangladesh was struggling to overcome environmental crises that drew the attention of global agencies to intervene with programmes of public awareness through radio. India, being a highly centralised democracy with tight controls over broadcasting which was a state monopoly then, offered an entirely different kind of ground for seeding the community radio projects.

If in Nepal independent radio emerged outside the state control, in Sri Lanka it could emerge within the state structure. In both countries, the community broadcasting experience took root without specific policy definition. In India, the policy response did not come till after the Indian private media entities were well on their way to domination of the information universe, threatening the viability of Prasar Bharati, which was a state-run broadcast monopoly till then.

Raghunath unpacks the debates around policy moves in each of the countries through personal interviews, documents and historical events. From her account we find out that Dr Sarath Amanugama, a long-time associate of Prof Dallas Smythe, facilitated the community radio initiative in Sri Lanka in 1979. Significantly, 1970s was also the period that marked intense global political ferment around equitable trade and information flows between the North and the South.

The United Nations was the platform through which the unequal global order was challenged and resulted in two major reports in 1980 - the Brandt Report titled NorthSouth: A Programme for Survival that addressed the North-South imbalances in trade, and the McBride Report titled "Many Voices, One World" that addressed imbalances in the information flows. Both the reports had a significant impact on policies of the countries in the global South.

The first resistance to the information imbalance came from the Latin American scholars who began to challenge the certitudes of the Development Decades. One of the alternative perspectives that began to be espoused widely was the Freirean participatory model of development and communication. The conception of community radio as a technological facilitator for participatory communication emerged from the empirical models that already existed in the Latin American context. Perhaps to retain the focus on the four countries in her study, Raghunath refers to these briefly but does not elaborate on this aspect of the global history of community radio.

Raghunath's exploration of the history and context that shaped the community radio initiatives in all the four countries of South Asia introduces us to the constraints and 
pressures of state control that drag the policy back into a developmentalist framework, for survival and for legitimacy. When power is increasingly centralised, and insecure, allowing for pockets of grassroots autonomy becomes increasingly untenable for the state. Her discussion of the fears expressed by policy stakeholders, whether in India, Sri Lanka, Bangladesh or Nepal, about an autonomous communication system that ensures voice to the marginalised, exposes the vulnerability of such initiatives to political control.

The policy frameworks that emerge under such conditions tend to ensure the precarity of the system by clamping limitations on financial viability and technological possibilities, imposing eligibility criteria for license holders, irrational reporting requirements in day-to-day operations, and imposing must-carry rules that undermine the very autonomy of the stations.

Raghunath's narrative of the policy story of community radio pulls together history, political economy, and anecdotal evidence, all interwoven in a rich tapestry of theoretical context. It helps unpack the gaps between the expectations and the reality of community radio as it took root, and grew, in each of the four countries of South Asia, with similarities in policy frameworks, but fundamental differences in objectives and praxis. The impact of globalisation, opening up of the mainstream media to the market forces, and political turmoil, have all had their imprint on policy outcomes.

Preeti Raghunath's book Community Radio Policies in South Asia takes the reader on an interesting bumpy ride through the policy battles. But the book is equally rewarding for those merely curious to know about the community radio experience in South Asia, and for those looking for methodological alternatives available for policy study, and the vast theoretical resources that can be explored in such an endeavour.

\section{About the Author}

\section{Padmaja Shaw}

Padmaja Shaw is professor emerita of journalism at Osmania University, India. She graduated with a Master's degree in Journalism from Osmania University, India, and an MA (Telecommunications) from Michigan State University, USA. She completed a PhD in Development Studies and has taught at the Department of Communication and Journalism, Osmania University, and English and Foreign Languages University, India. She has two tracks of interest: Broadcast production and the political economy of communication. 